\title{
The effect of waste sulfur obtained during biogas desulfurization on the availability of selected trace elements in soil
}

\author{
Aneta Bobowiec, Monika Tabak \\ University of Agriculture, Department of Agricultural and Environmental Chemistry; al. A. Mickiewicza 21, 33-332 Krakow, \\ Poland; e-mail:aneta.bobowiec@gmail.com,monika.tabak@urk.edu.pl \\ (C) 2018 Authors. This is an open access publication, which can be used, distributed and reproduced in any medium according \\ to the Creative Commons CC-BY 4.0 License requiring that the original work has been properly cited.
}

Received: 28 June 2018; accepted: 26 September 2018; first published online: 16 October 2018

\begin{abstract}
Research concerning the effect of the application of waste sulfur pulp (doses: 10, 20, 30, $60 \mathrm{mg} \mathrm{S} \cdot \mathrm{kg}^{-1}$ d.m. of soil) on selected soil properties was carried out. The pulp contained sulfur in the elemental form. Before setting up the experiment, the soil had a slightly acid reaction (determination in $1 \mathrm{~mol} \cdot \mathrm{dm}^{-3} \mathrm{KCl}$ ) and was not contaminated with heavy metals. After conducting the incubation experiment, it was observed that the application of sulfur pulp led to a statistically significant (and proportional to the dose) increase in the content of available sulfur in soil. Application of waste caused a decrease in soil $\mathrm{pH}$ and an increase in the mobility and availability of $\mathrm{Zn}$, Cd and $\mathrm{Mn}$ (extracted with $0.01 \mathrm{~mol} \cdot \mathrm{dm}^{-3} \mathrm{CaCl}_{2}$ ). In relation to soil without waste, more $\mathrm{Zn}$, Cd and $\mathrm{Mn}$ (by $4-51 \%, 9-24 \%$ and $0.1-31 \%$, respectively) was determined. Liming reduced the acidifying effect of the introduced waste - after 150 days, only soil with the highest dose of sulfur pulp was characterized by a statistically significantly lower $\mathrm{pH}$ than the soil without the waste addition. An increase in the rate of sulfur oxidation was also observed - after 150 days of the experiment, more sulfate sulfur (by 14.4-34.5\%) was determined, with respect to treatments of the unlimed series. A considerably lower content of $\mathrm{Zn}, \mathrm{Cd}$ and $\mathrm{Mn}$ was determined in the limed soil than in the unlimed one. Regardless of waste dose and date of analysis, the soil contained a trace content of mobile forms of $\mathrm{Cu}, \mathrm{Cr}, \mathrm{Ni}$ and $\mathrm{Pb}$.
\end{abstract}

Keywords: elemental sulfur, sulfur pulp, waste, trace elements

\section{INTRODUCTION}

Formation of sewage sludge (as a by-product) is a result of a series of physical, chemical and biological processes taking place in sewage treatment plants (Kwaśny et al. 2016). Its production in Poland is increasing and currently more than $650,000 \mathrm{Mg}$ d.m. of sewage sludge is produced annually in municipal sewage treatment plants. It is estimated that by 2020 the amount of sludge production will exceed 780,000 Mg d.m. per year (Barbusiński 2016). Because of the increasing limitations regarding the use of this material, alternative means of its disposal are being sought.
One way of sludge processing into waste which is safe for the environment is to subject it to methane fermentation, during which a gas fuel - biogas - is additionally formed as a by-product (Krzemień 2012). As a result of processing $1 \mathrm{~m}^{3}$ of sewage sludge containing 4-5\% d.m., $10-20 \mathrm{~m}^{3}$ of this fuel is obtained (Kowalczyk-Juśko 2013). It is a mixture of gases, among which one can distinguish (above all): methane (67\%), carbon dioxide (30\%) and hydrogen sulfide (2\%) (Sadecka 2010). Hydrogen sulfide present in the raw biogas reduces its energy value, destroys parts of the installations used for its conversion, and contaminates the environment when released (Kowalczyk-Juśko 2013, 
Kuziemska et al. 2015). To eliminate this component, biogas is subjected to desulfurization (Kwaśny et al. 2016). The choice of desulfurization method depends, among other things, on the amount of hydrogen sulfide present in the biogas. Solid sorbents, living microorganisms and chemical compounds can be used (Żarczyński et al. 2014, Kwaśny et al. 2016). In Poland, biogas desulfurization is carried out, among other things, using the Biosulfex method, which is based on the application of chemical compounds (iron and organic ligand EDTA). It is one of the most frequently used methods in the case of the purification of gas obtained from sewage sludge fermentation (Kociołek-Balawejder \& Wilk 2011). Its application leads to hydrogen sulfide elimination at a level of $98 \%$, and sulfur accumulated in the form of sulfur pulp is a material that can be used as a substrate for the manufacture of pesticides and fertilizers (Kociołek-Balawejder \& Wilk 2011, Piskowska-Wasiak 2013).

Progressive greening of the environment, intensive crop production, limited consumption of natural fertilizers and pesticides containing sulfur are the main causes of a gradual decrease in the content of sulfur compounds in soil (Kaczor \& Zuzańska 2009, Klikocka et al. 2015, Pietrzak 2015). In 2015, 92\% of arable soils in Poland were characterized by their low content of the available form of this element (Monitoring chemizmu gleb, on-line), which points to the necessity of taking sulfur into account in plant fertilization (Klikocka et al. 2015), especially for crops with higher demands for sulfur, such as oilseed crops (Hřivna et al. 2002, Šípalová et al. 2011).

Fertilization with elemental sulfur may lead to a decrease in soil pH (Kulczycki 2004). Oxidation of the introduced element leads to an increase in the concentration of acid ions $\left(\mathrm{H}^{+}\right)$. Thiobacillus thioxidans - an obligate aerobe that transforms sulfur into a phytoavailable form - may cause a decrease in soil pH into 2-3 (Yang et al. 2010, Filipek \& Skowrońska 2013).

Reaction is an important feature that determines many processes in the soil environment. It influences mobility, forms of occurrence and availability of heavy metals in soil; the availability of heavy metals increases in an acid environment. This may lead to their accumulation in plants to a toxic level (Haling et al. 2011, Filipek \& Skowrońska 2013, Vollmann et al. 2015, Onwuka et al. 2016). Moreover, under low soil $\mathrm{pH}$ conditions, immobilization of soluble forms of nutrients essential for plants (e.g. phosphorus) takes place. Soil biological activity is also reduced, which negatively influences organic substance transformations. The number of soil-transmitted diseases and the number of organisms resistant to acid reaction, e.g. fungi, increases (Tkaczyk \& Bednarek 2011, Onwuka et al. 2016).

One of the ways to reduce the negative effects of acidification is to increase soil $\mathrm{pH}$ through soil liming (Lošák et al. 2012, Goulding 2016, Onwuka et al. 2016).

The aim of this paper was to assess the effect of the application of waste sulfur pulp on the $\mathrm{pH}$ of the incubated soil, sulfate sulfur content, as well as on the mobility of selected trace elements. The research was conducted in two series: limed and unlimed. Liming enabled the comparison of the effect of soil $\mathrm{pH}$ on the changes in the availability of elements after the application of elemental sulfur.

\section{MATERIALS AND METHODS}

Medium soil (agronomic category of soil, determined based on the content of fraction $<0.02 \mathrm{~mm}$ ) with acid reaction was used in the incubation experiment (Tab. 1). The examined soil was characterized by an average content of sulfate and total sulfur and was not contaminated with heavy metals, established based on the guidelines of the Institute of Soil Science and Plant Cultivation (IUNG) (Kabata-Pendias et al. 1995).

The incubation experiment design comprised six treatments:

1) control soil (with no additions) - treatment $A$,

2) soil with the addition of sulfur pulp (sulfur dose: I) - treatment B,

3) soil with the addition of sulfur pulp (sulfur dose: II) - treatment C,

4) soil with the addition of sulfur pulp (sulfur dose: III) - treatment D,

5) soil with the addition of sulfur pulp (sulfur dose: IV) - treatment E,

6) soil with the addition of ammonium sulfate (sulfur dose: II) - treatment F. 
Table 1

Selected soil properties before setting up the experiment

\begin{tabular}{|c|c|c|c|}
\hline \multicolumn{2}{|c|}{ Parameter } & Unit & Value \\
\hline \multicolumn{2}{|c|}{ Fraction $1-0.1 \mathrm{~mm}$} & \multirow{4}{*}{$\%$} & 39 \\
\hline \multicolumn{2}{|c|}{ Fraction $0.1-0.02 \mathrm{~mm}$} & & 34 \\
\hline \multicolumn{2}{|c|}{ Fraction $<0.02 \mathrm{~mm}$} & & 27 \\
\hline \multicolumn{2}{|l|}{ PWmax } & & 25.88 \\
\hline \multicolumn{2}{|l|}{$\mathrm{pH}_{\mathrm{H}_{2} \mathrm{O}}$} & - & 6.16 \\
\hline \multicolumn{2}{|l|}{$\mathrm{pH}_{\mathrm{KCl}}$} & - & 5.35 \\
\hline \multicolumn{2}{|l|}{$\mathrm{Hh}$} & $\mathrm{mmol}(+) \cdot \mathrm{kg}^{-1}$ d.m. & 15.5 \\
\hline \multicolumn{2}{|l|}{$\mathrm{S}-\mathrm{SO}_{4}$} & $\mathrm{mg} \cdot \mathrm{kg}^{-1}$ d.m. & 30.0 \\
\hline \multirow{9}{*}{$\begin{array}{l}\text { Total } \\
\text { content }\end{array}$} & $\mathrm{Fe}$ & $\mathrm{g} \cdot \mathrm{kg}^{-1}$ d.m. & 6.71 \\
\hline & $S$ & \multirow{8}{*}{$\mathrm{mg} \cdot \mathrm{kg}^{-1}$ d.m. } & 148.3 \\
\hline & $\mathrm{Cr}$ & & 10.1 \\
\hline & $\mathrm{Zn}$ & & 73.2 \\
\hline & $\mathrm{Pb}$ & & 20.1 \\
\hline & $\mathrm{Cu}$ & & 4.77 \\
\hline & $\mathrm{Cd}$ & & 0.44 \\
\hline & $\mathrm{Ni}$ & & 6.80 \\
\hline & $\mathrm{Mn}$ & & 324 \\
\hline
\end{tabular}

Sulfur pulp doses were established on the basis of the content of sulfate sulfur in the soil material before setting up the incubation experiment and based on the guidelines of the Institute of Soil Science and Plant Cultivation on the limit content of sulfur in soil (Kabata-Pendias et al. 1995). Sulfur pulp was applied in four doses:

1) $10 \mathrm{mg} \mathrm{S} \cdot \mathrm{kg}^{-1} \mathrm{~d} . \mathrm{m}$. of soil,

2) $20 \mathrm{mg} \mathrm{S} \cdot \mathrm{kg}^{-1} \mathrm{~d} . \mathrm{m}$. of soil,

3) $30 \mathrm{mg} \mathrm{S} \cdot \mathrm{kg}^{-1} \mathrm{~d} . \mathrm{m}$. of soil,

4) $60 \mathrm{mg} \mathrm{S} \cdot \mathrm{kg}^{-1} \mathrm{~d} . \mathrm{m}$. of soil.

Ammonium sulfate was introduced to compare the rate of elemental sulfur transformation with the availability of sulfate sulfur present in the conventional fertilizer $\left(20 \mathrm{mg} \mathrm{S} \cdot \mathrm{kg}^{-1} \mathrm{~d}\right.$. $\mathrm{m}$. of soil was introduced with the fertilizer).

The research was conducted in two series: the first one was unlimed $(0 \mathrm{Ca})$ and the second one was limed $(+\mathrm{Ca})$. Carbide lime was used for liming and was introduced to the soil two months prior to sulfur application. Lime dose was established so as to neutralize the soil acidification that corresponds to hydrolytic acidity (1 Hh).

The used waste materials - sulfur pulp and carbide lime - came from the Municipal-Industrial Sewage Treatment Plant in Oświęcim, Poland. Sulfur pulp is a product generated in the process of biogas desulfurization by means of the Biosulfex method. This material contained $54.7 \%$ a.d.m., from which elemental sulfur constituted over $90 \%$; the content of the other elements was insignificant from the point of view of agricultural use (Tab. 2). Carbide lime - created in the process of acetylene production with carbide use - was characterized by alkalinity amounting to $67.4 \% \mathrm{CaO}$ (Tab. 2).

Table 2

Selected chemical properties of sulfur pulp and carbide lime

\begin{tabular}{|c|c|c|c|c|}
\hline \multicolumn{2}{|c|}{ Parameter } & Unit & $\begin{array}{c}\text { Sulfur } \\
\text { pulp }\end{array}$ & $\begin{array}{c}\text { Carbide } \\
\text { lime }\end{array}$ \\
\hline \multicolumn{2}{|l|}{ a.d.m. } & $\%$ & 54.7 & 62.3 \\
\hline \multicolumn{2}{|c|}{ alkalinity } & $\% \mathrm{CaO}$ & - & 67.4 \\
\hline \multirow{9}{*}{$\begin{array}{l}\text { Total } \\
\text { content }\end{array}$} & $\mathrm{C}$ & \multirow{9}{*}{$\mathrm{g} \cdot \mathrm{kg}^{-1}$ d.m. } & 13.5 & 52.4 \\
\hline & $\mathrm{N}$ & & 0.95 & 0.56 \\
\hline & $\mathrm{P}$ & & traces & 0.17 \\
\hline & $\mathrm{K}$ & & traces & traces \\
\hline & $\mathrm{Ca}$ & & 0.276 & 395 \\
\hline & $\mathrm{Mg}$ & & traces & 1.79 \\
\hline & $\mathrm{Na}$ & & 10.5 & traces \\
\hline & $\mathrm{Fe}$ & & 2.13 & 0.764 \\
\hline & $S$ & & 921 & 1.13 \\
\hline
\end{tabular}

The content of heavy metals in the waste materials used in the experiment was considerably lower than the permissible content in organic and mineral fertilizers as well as in sewage sludge used for fertilization (Tab. 3). Only the water content in carbide lime was higher than the limit content for types of lime not containing magnesium (Rozporządzenie 2010). Carbide lime is also a waste material which is permitted for use in the R10 recovery process (R10 means "Treatment on the soil surface that brings benefits to agriculture or improvement of environment condition") (Rozporządzenie 2015b). Importantly, sulfur pulp is not mentioned in the regulation of the Minister of Environment concerning the R10 recovery process (Rozporządzenie 2015b), thus there is no possibility of its direct use to improve soil properties. A possible way of managing the described waste is to utilize it as an amendment enriching other materials or fertilizers with sulfur. In order to use a newly created product as a fertilizer or an agent improving soil properties, permission of the Minister of Agriculture and Rural Development must be obtained, according to the act on fertilizers and fertilization (Ustawa 2007) and executive regulations. 
Table 3

Content of heavy metals in sulfur pulp and carbide lime with permissible content in fertilizers and materials used for fertilization $\left[\mathrm{mg} \cdot \mathrm{kg}^{-1}\right.$ d.m.]

\begin{tabular}{|l|c|c|c|c|c|}
\hline \multirow{2}{*}{ Element } & Sulfur pulp & \multirow{2}{*}{ Carbide lime } & \multicolumn{3}{|c|}{ Permissible content $^{*}$} \\
\cline { 4 - 6 } & & & sewage sludge & $\begin{array}{c}\text { organic } \\
\text { fertilizers }\end{array}$ & $\begin{array}{c}\text { mineral } \\
\text { fertilizers }\end{array}$ \\
\hline $\mathrm{Zn}$ & 5.06 & 5.26 & 2,500 & - & - \\
\hline $\mathrm{Ni}$ & traces & 3.94 & 300 & 60 & - \\
\hline $\mathrm{Cd}$ & traces & 0.32 & 20 & 5 & 50 \\
\hline $\mathrm{Cu}$ & 2.25 & 5.62 & 1,000 & - & 140 \\
\hline $\mathrm{Pb}$ & 1.74 & traces & 750 & 140 & - \\
\hline $\mathrm{Cr}$ & 4.02 & 5.28 & 500 & 100 & 2 \\
\hline $\mathrm{Hg}$ & not determined & 0.274 & 16 & 2 & \\
\hline
\end{tabular}

* source: Rozporządzenie 2008, Rozporządzenie 2015a

The soil was placed in plastic containers ( $280 \mathrm{~g}$ d.m. of soil enriched with appropriate substances - according to the experimental design was introduced to each container). Throughout the period of the experiment, water losses were replenished periodically in order to maintain the humidity of the soil material at $60 \%$ of the maximum water capacity. Incubation was conducted at the temperature of $25 \pm 2^{\circ} \mathrm{C}$. Soil for analyses was collected on the day of sulfur fertilization as well as 150 days after sulfur introduction. The material was dried and sieved ( $1 \mathrm{~mm}$ mesh size) in order to prepare it for laboratory analyses.

Soil $\mathrm{pH}$ was determined by potentiometry, using $1 \mathrm{~mol} \cdot \mathrm{dm}^{-3}$ potassium chloride solution (Ostrowska et al. 1991). The content of sulfate sulfur and trace elements $(\mathrm{Cd}, \mathrm{Cr}, \mathrm{Cu}, \mathrm{Mn}, \mathrm{Ni}, \mathrm{Pb}, \mathrm{Zn})$ was determined after extracting the soil samples with calcium chloride solution $\left(0.01 \mathrm{~mol} \cdot \mathrm{dm}^{-3}\right.$, $2 \mathrm{~h}, 40 \mathrm{rpm}$ ), at 10:1 (v:m) ratio (Ostrowska et al. 1991, Curyło et al. 2007). The content of sulfate sulfur and selected trace elements in the obtained extracts was determined by ICP-OES (inductively coupled plasma optical emission spectrometry) on a PerkinElmer Optima 7300 DV. The obtained results were subjected to a two-factor analysis of variance (factor 1: treatment, factor 2: the number of days of incubation). Significance of differences in mean values was determined using the Tukey test, at the significance level of $\alpha \leq 0.05$. Statistical analysis of the results was carried out using Statistica 12 software (StatSoft, Inc.).
In order to determine the properties of the soil, sulfur pulp and carbide lime, additional analyses were performed before setting up the experiment. Granulometric composition of the soil was determined using the Bouyoucos-Casagrande aerometric method in Prószyński’s modification (Ostrowska et al. 1991). This method of granulometric composition determination was applied since it conforms with the method for determining sulfur content in soils (Kabata-Pendias et al. 1995). Maximum water capacity of the soil was determined by measuring the difference in soil mass before and after moisture conditioning by capillary rise. Hydrolytic acidity (Hh) was determined by Kappen method (Ostrowska et al. 1991). Sulfate sulfur was extracted from the soil with acetic acid solution $\left(0.03 \mathrm{~mol} \cdot \mathrm{dm}^{-3}, 20 \mathrm{~min}, 40 \mathrm{rpm}\right)$, at 10:1 (v:m) ratio (Ostrowska et al. 1991) and determined by ICP-OES. Total content of heavy metals in the soil was also determined by ICP-OES, after dry mineralization $\left(450^{\circ} \mathrm{C}, 12 \mathrm{~h}\right)$ and digestion of the remains in a mixture of concentrated nitric acid and perchloric acid (3:2, v:v) (Ostrowska et al. 1991).

Absolute dry matter of sulfur pulp and carbide lime was determined by the weight method (Baran \& Turski 1999). Alkalinity of carbide lime was determined after reaction with hydrochloric acid and back titration of the acid with sodium hydroxide. Total content of carbon and nitrogen in both materials was determined in a vario MAX cube CNS analyzer (Elementar Analysensysteme $\mathrm{GmbH}$ ) 
(Operating instructions 2013). Total content of sulfur in sulfur pulp was determined after reaction with hydrogen peroxide in an alkaline environment (EN 15925), whereas in carbide lime this was after binding sulfur by magnesium nitrate, thermal decomposition and dissolving the remains in nitric acid (Ostrowska et al. 1991). Other macroelements and all microelements (except mercury) in both materials were determined after thermal decomposition and digestion in inorganic acids, under conditions suitable to the properties of the materials. The content of analyzed elements in the obtained solutions was determined by ICP-OES. Total content of mercury in carbide lime was determined on AMA-254 (Altec Ltd.) apparatus.

\section{RESULTS AND DISCUSSION}

Soil reaction is an important parameter that shapes the physicochemical and biological processes taking place in the soil, and as a result regulates plant growth and development. This feature is characterized by variability, which results from the influence of external factors (Mudlaff et al. 2016). Soil fertilization with elemental sulfur may lead to the formation of mineral acids that acidify soils (Kulczycki 2004).
On the day of sulfur application, diversity in the $\mathrm{pH}$ of soil of each series (unlimed and limed) was small, statistical differences applied only to some treatments (Fig. 1). 150 days after sulfur introduction, soil with the addition of sulfur pulp at dose IV (60 mg S. $\mathrm{kg}^{-1} \mathrm{~d} . \mathrm{m}$. of soil) and with the addition of conventional fertilizer - ammonium sulfate (with which $20 \mathrm{mg} \mathrm{S} \cdot \mathrm{kg}^{-1} \mathrm{~d}$.m. of soil was introduced) had the lowest $\mathrm{pH}$ value (Fig. 1). The $\mathrm{pH}$ value of the soil of the remaining unlimed treatments did not differ statistically significantly. The same relations applied to the limed soil.

Liming significantly changed the soil reaction from acid to slightly acid (Fig. 1). It limited the acidifying effect of processes occurring in the soil - in comparison with the day of sulfur application, after 150 days of incubation only the $\mathrm{pH}$ value of the soil fertilized with the highest dose of pulp and with ammonium sulfate decreased statistically significantly (Fig. 1). During incubation, a decrease in $\mathrm{pH}$ of the unlimed soil of all treatments was determined.

Based on the conducted experiment, it can be stated that application of sulfur pulp, as well as ammonium sulfate, caused a change in the $\mathrm{pH}$ of the investigated soil. The acidifying effect of sulfur was shown also by Kulczycki (2004), Podleśna (2005), Kulczycki et al. (2007), Yang et al. (2010). Liming reduces this phenomenon.

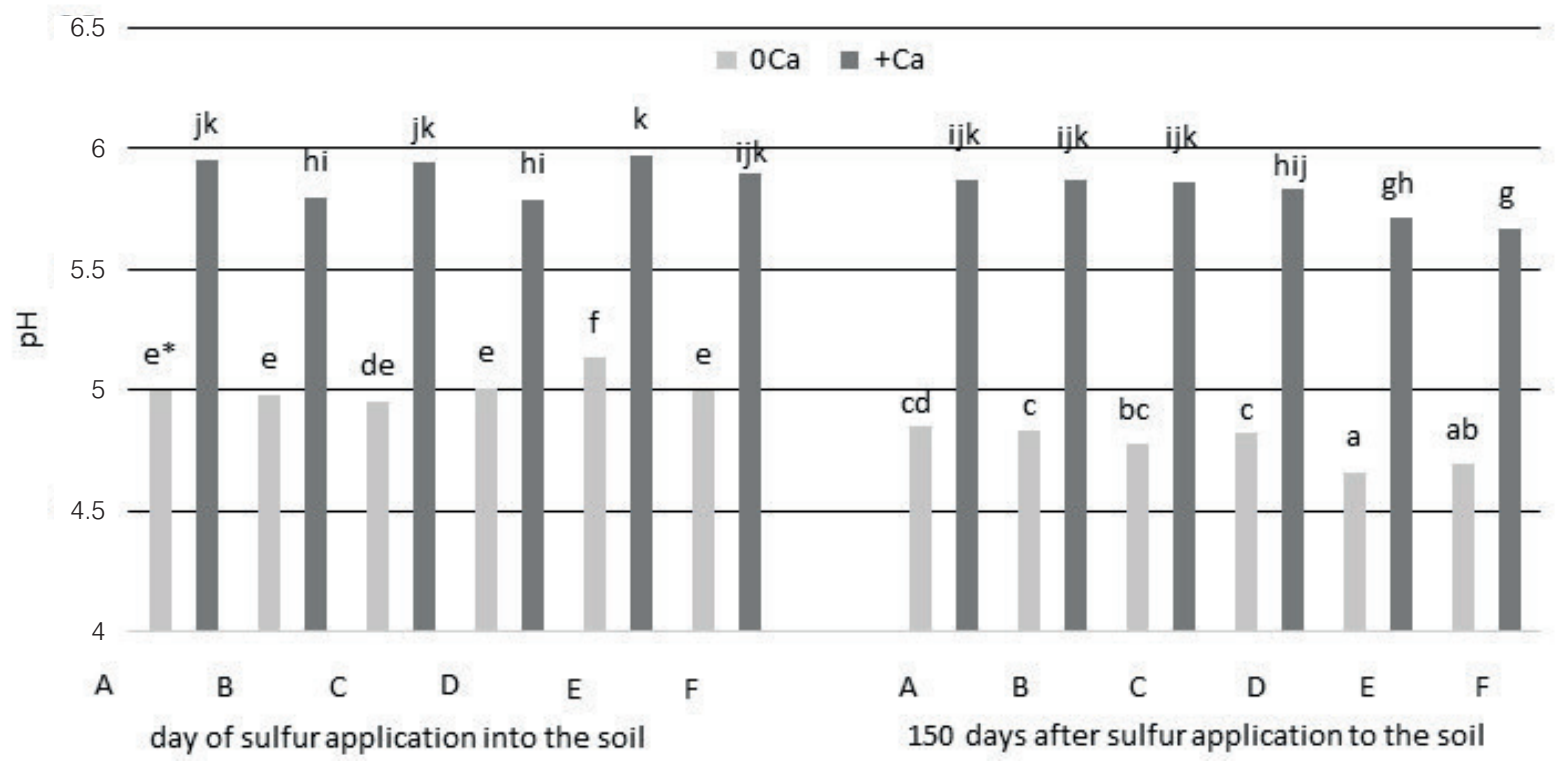

Fig. 1. Soil pH value on the day of sulfur application and after 150 days. Explanations: mean values marked with the same letters do not differ statistically significantly at the significance level $\alpha \leq 0.05$; according to Tukey test 
Sulfur occurs in soil mainly in organic form, but in order to be absorbed by plants it must be transformed into inorganic sulfate form. Using elemental sulfur is an alternative to using traditional mineral fertilizers (containing sulfate sulfur) (Hoffmann et al. 2014). This form of sulfur acts much slower, because it needs oxidation before it becomes available to plants (Yang et al. 2010, Barczak et al. 2016). Optimum conditions for this process are: temperature $20-30^{\circ} \mathrm{C}$, soil $\mathrm{pH}$ about 6.0-7.0 as well as moisture at a level of approximately 60\% (Hoffman et al. 2014).

On the day of pulp application, no statistically significant influence of this procedure on the content of sulfate sulfur in the soil was observed (Fig. 2), which was a result of chemical form of introduced sulfur. Applied elemental sulfur requires oxidation to the sulfate form. On the day of application of sulfur-containing materials, only application of ammonium sulfate (at dose II: $20 \mathrm{mg} \mathrm{S} \cdot \mathrm{kg}^{-1} \mathrm{~d}$.m. of soil) significantly influenced the content of sulfate sulfur in the soil.

150 days after sulfur introduction, the soil without additions and with the addition of sulfur pulp at dose I (10 mg $\cdot \mathrm{kg}^{-1} \mathrm{~d} . \mathrm{m}$. of soil) had the lowest content of sulfates. The highest content of sulfates was determined in the soil with the addition of sulfur pulp at dose IV $\left(60 \mathrm{mg} \cdot \mathrm{kg}^{-1} \mathrm{~d}\right.$.m. of soil) - this applies to both the unlimed and limed soil (Fig. 2). The most visible change in sulfate sulfur content over time was recorded in soil with the addition of sulfur at dose IV; an increase by $40.3 \mathrm{mg} \cdot \mathrm{kg}^{-1}$ d.m. and $53.4 \mathrm{mg} \cdot \mathrm{kg}^{-1} \mathrm{~d}$.m. in the content of sulfate sulfur was recorded in the unlimed and limed soil, respectively (Fig. 2).

Liming caused a change in sulfate sulfur content in the soil in comparison with the unlimed soil. Generally, a significantly higher content of sulfate sulfur was determined in the limed soil than in the unlimed soil.

After the incubation experiment, it was established that the application of sulfur in the elemental and ionic form influenced the content of the available form of this element in the soil, in comparison with the content determined in the soil with no additions. Intensity of transformations of the introduced sulfur pulp (at doses 10, 20, 30 and $60 \mathrm{mg} \mathrm{S} \cdot \mathrm{kg}^{-1} \mathrm{~d} . \mathrm{m}$. of soil) into sulfate form amounted to $14.3 \%, 31.8 \%, 38.4 \%$ and $61.3 \%$, respectively in the unlimed soil, whereas in the limed soil to $100 \%, 73.9 \%, 90.6 \%$ and $98.0 \%$. On the day of sulfur introduction to the soil, the content of sulfate sulfur determined in the unlimed and limed soil indicated natural content of sulfate form of this element in the soil. After 150 days of the experiment, the increase in sulfate sulfur content in the soil was so strong that the determined content of sulfates pointed to anthropogenically elevated content. Only in the unlimed soil with the addition of sulfur pulp at dose I, was no elevated sulfate sulfur content observed (Fig. 2).

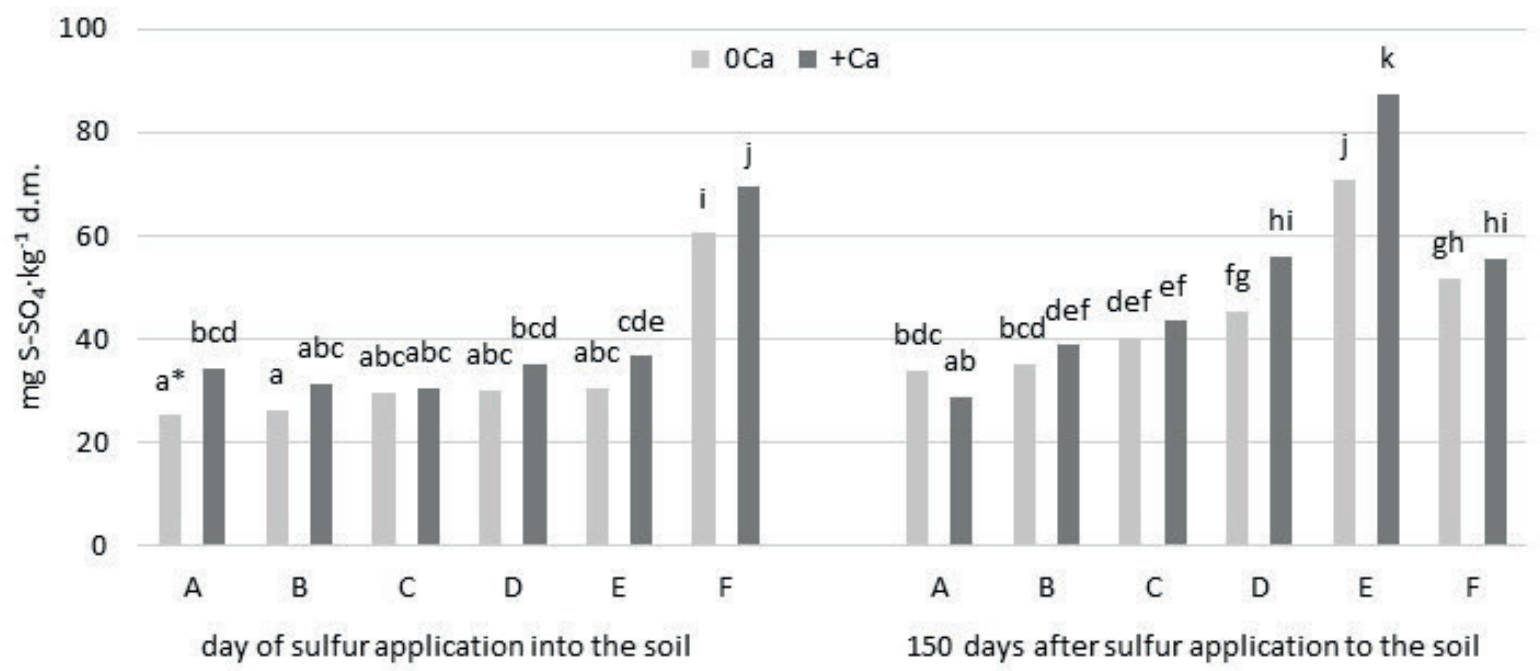

Fig. 2. Content of sulfate sulfur in the soil on the day of sulfur introduction and after 150 days. Explanations: see Figure 1 
The increasing sulfate sulfur content in the unlimed and limed soil indicates gradual oxidation of elemental sulfur introduced as sulfur waste. The course of this process depends on a number of factors, including the activity, number and composition of population of soil organisms (influencing biological oxidation of sulfur), degree of fineness of introduced material, and also moisture, temperature and reaction of soil (Wen et al. 2001). According to Kulczycki (2003) as well as Klikocka \& Sachajko (2011), the gradual release of the ionic form of sulfur can be beneficial when using elemental sulfur on soils prone to leaching. Additionally, because of the gradual release of sulfates, fertilization with elemental sulfur can be done once every few years.

The solubility of trace elements in the soil environment depends, among other things, on its reaction (Gambuś et al. 2005). Low soil pH favors the manifestation of trace element toxicity, whereas high $\mathrm{pH}$ leads to the transformation of trace elements into forms of low availability to plants (Mudlaff et al. 2016).

On the day of the application of pulp and ammonium sulfate, no statistically significant effect of this procedure on zinc content in the soil was observed (Fig. 3).

150 days after sulfur application, the unlimed and limed soil with the addition of sulfur pulp at dose IV and ammonium sulfate at dose II had significantly the highest content of soluble forms of zinc (Fig. 3). The lowest zinc content was determined in the unlimed and limed soil with the addition of sulfur pulp at dose I, as well as in the soil with no additions. The most visible change in zinc content over time was recorded in the soil with the addition of sulfur at dose IV; over a two- and a sixfold increase in the content of soluble forms of zinc were recorded in the unlimed and limed soil, respectively.

Liming significantly changed the content of available forms of zinc in the soil. The unlimed soil had a higher zinc content than the limed soil (Fig. 3). The unlimed soil with the sulfur pulp addition (at doses I, II, III, IV) had 11-times more of the soluble forms of zinc than the limed soil. This resulted from the fact that the unlimed soil had the lower $\mathrm{pH}$ value, which was directly caused by the acidifying effect of the introduced sulfur waste. It indicates increased availability of zinc under acid $\mathrm{pH}$. This element is taken up by plants in the form of mono- or divalent ion $\left(\mathrm{Zn}(\mathrm{OH})^{+}, \mathrm{Zn}^{2+}\right)$. As a result of soil liming, poorly soluble forms of zinc are formed, which results in reducing its availability to plants (Burzyńska 2009). Decreasing zinc content in soil as a result of liming was shown also by Burzyńska (2009) and Kuziemska et al. (2014).

On the day of sulfur application, diversity in manganese content in the soil of each series was low, statistical differences applied only to some treatments (Fig. 4).

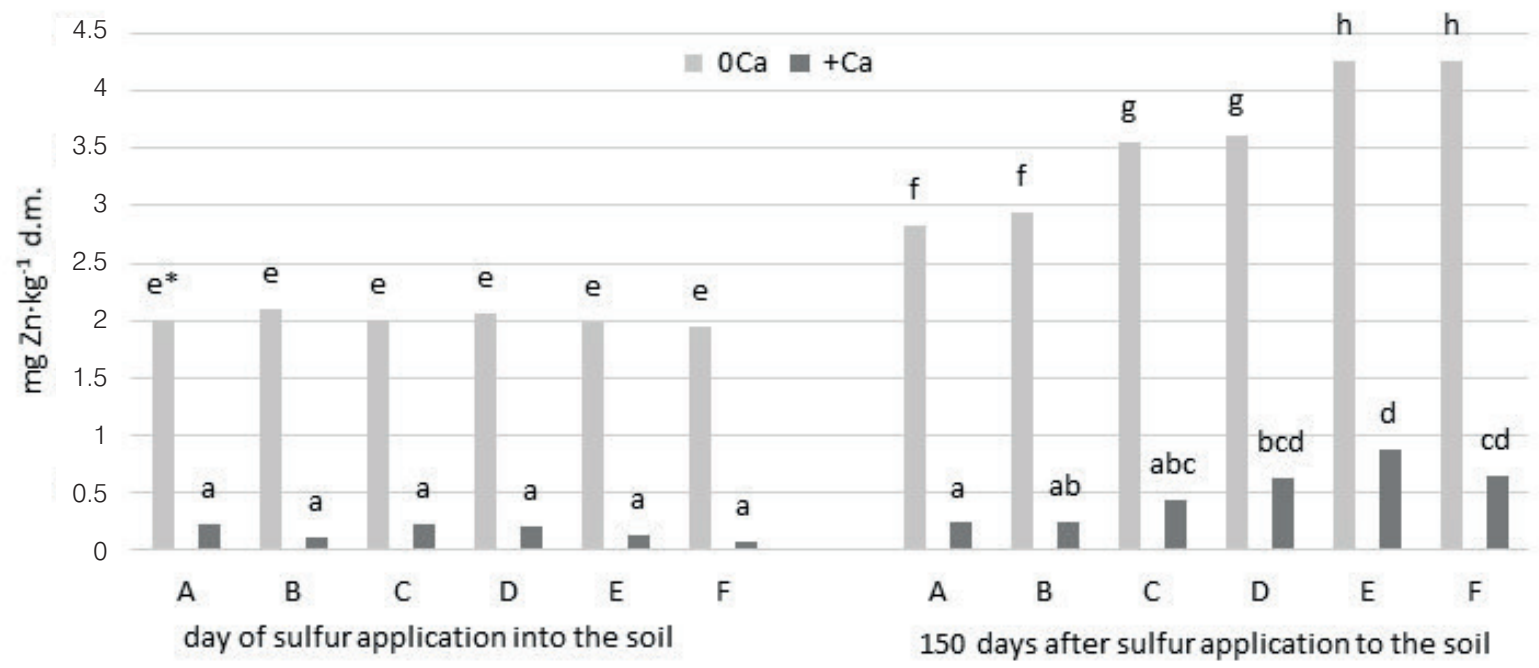

Fig. 3. Zinc content in the soil on the day of sulfur introduction and after 150 days. Explanations: see Figure 1 


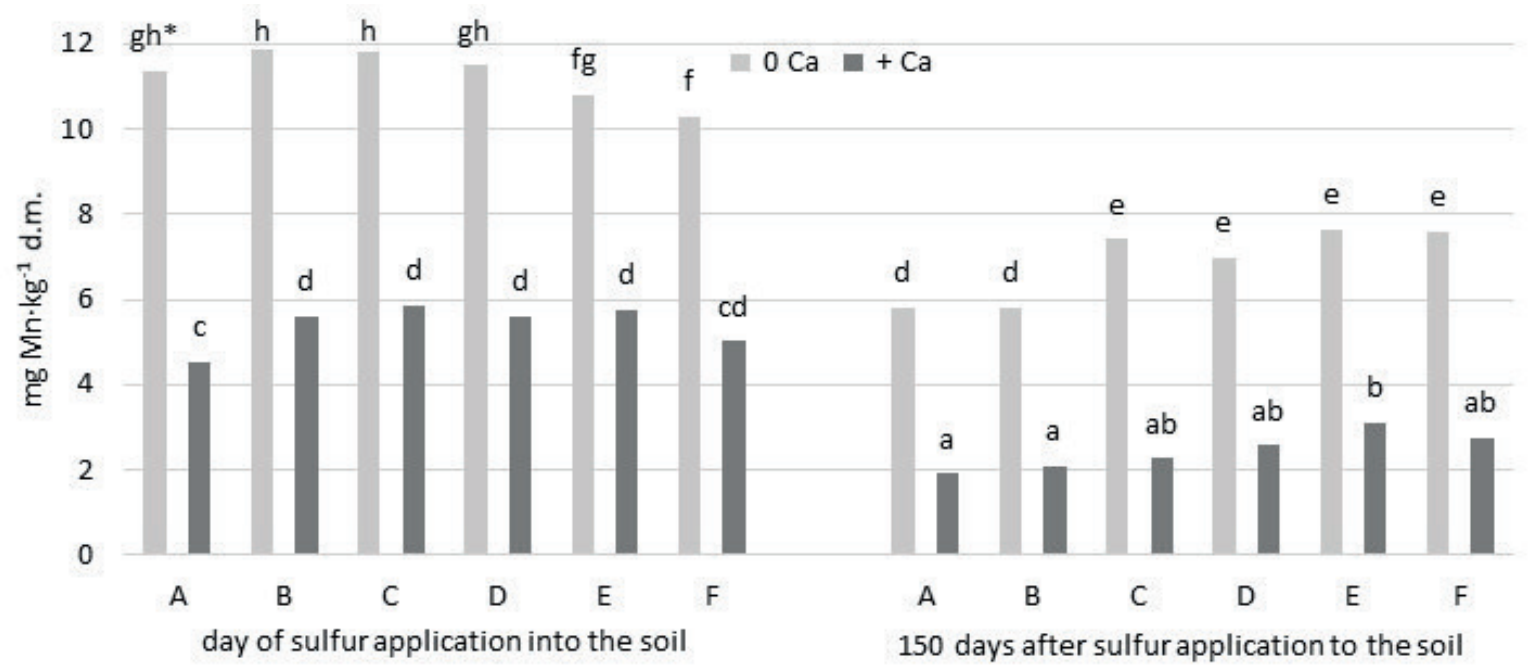

Fig. 4. Manganese content in the soil on the day of sulfur introduction and after 150 days. Explanations: see Figure 1

After 150 days of the experiment, manganese content in the unlimed and limed soil decreased. Within each series, soil with the addition of sulfur pulp at dose IV and ammonium sulfate at dose II had significantly the highest manganese content (Fig. 4).

Our research showed that liming significantly reduced the content of soluble forms of manganese in the soil (Fig. 4). The limed soil with the sulfur pulp addition (at doses I, II, III, IV) had a $40 \%$ lower content of soluble manganese than the unlimed soil (Fig. 4).

According to Rajmund \& Bożym (2017), the content of available forms of manganese in the same soil varies over time. Important factors influencing soil richness in this metal include soil reaction, aeration and richness in humus. Because of the reduced binding of manganese by organic matter, this metal is relatively mobile in the soil (Jaworska 2012). In acid soils, higher quantities of divalent manganese are transferred into multivalent, which translates into higher mobility of this element in soil (Rajmund \& Bożym 2017). Lowering of soil $\mathrm{pH}$ intensifies the uptake of this element by plants, causing an increase in its content in the plant organism, often reaching toxic values (High 2011). Bolan et al. (2003), Brzeziński \& Sosulski (2009), Wysokiński (2011) as well as Rengel (2015) also wrote about manganese retardation after liming.
On the day of pulp application, no statistically significant effect of this procedure on the content of cadmium in the limed and unlimed soil was observed (Fig. 5).

150 days after sulfur introduction, an increase in cadmium content in the unlimed soil with the addition of sulfur pulp (at doses I, II, III, IV) was recorded. In the limed soil, only application of two highest doses of sulfur waste ( 30 and $60 \mathrm{mg} \mathrm{S} \cdot \mathrm{kg}^{-1} \mathrm{~d} . \mathrm{m}$. of soil) led to a statistically significant increase in the content of soluble cadmium (Fig. 5). The unlimed and limed soil with the addition of sulfur pulp at dose IV had significantly the highest content of this element, whereas the lowest content was observed after the application of sulfur pulp at dose I.

Liming reduced the availability of soluble cadmium, over a $50 \%$ reduction in the content of this element in the soil with the addition of sulfur pulp (at doses I, II, III, IV) was recorded. As a result of the increase in soil $\mathrm{pH}$, immobilization of the mentioned element occurs and it precipitates as carbonates and hydroxides, which makes leaching difficult (Gambuś et al. 2005, Nazarkiewicz \& Kaniuczak 2012). Zaniewicz-Bojakowska et al. (2009), Nazarkiewicz \& Kaniuczak (2012), as well as Gambuś et al. (2005) also found a reduction in the content of soluble cadmium in limed soil. Jackowska \& Bojanowska (2000) also confirmed the increase in mobility of soluble cadmium in acidified soil. 


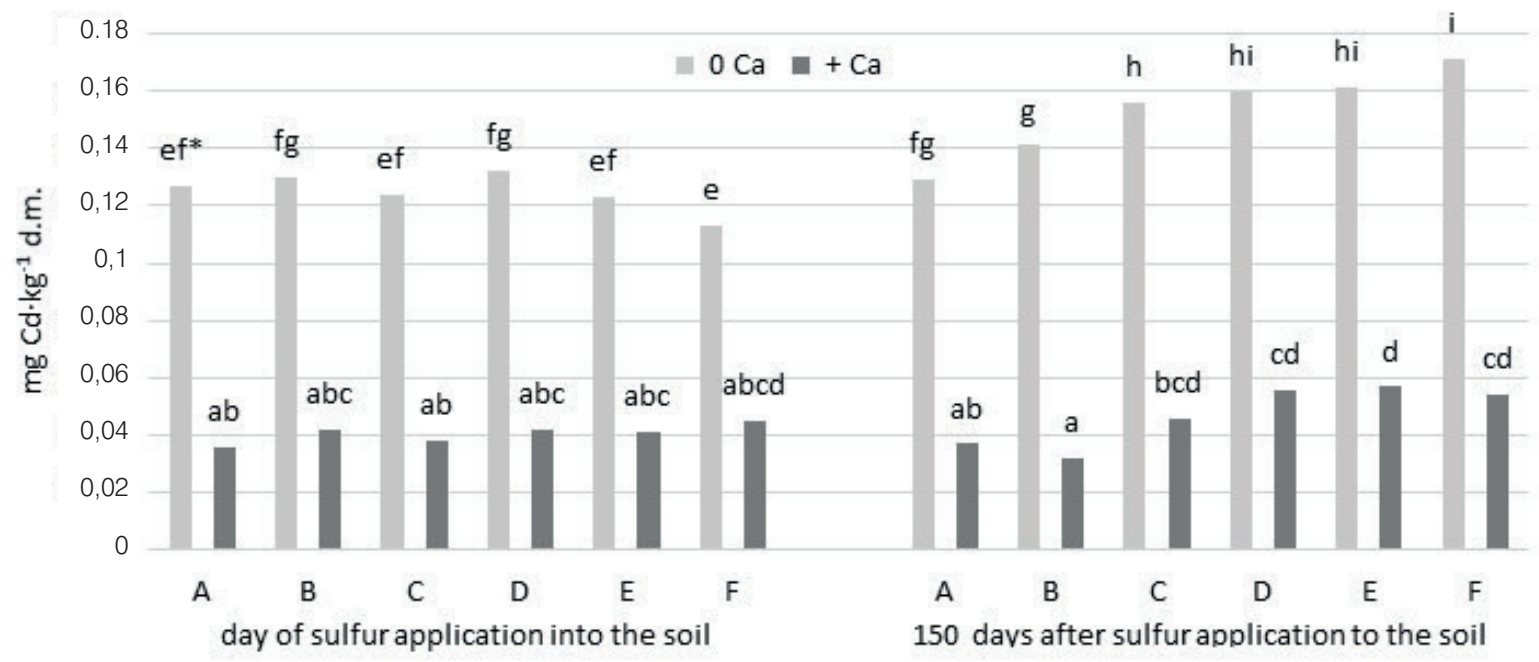

Fig. 5. Cadmium content in the soil on the day of sulfur introduction and after 150 days. Explanations: see Figure 1

Cadmium is a toxic element from the group of heavy metals, which in the plant organism has no metabolic functions. It is available to plants in the form of $\mathrm{Cd}^{2+}$ ion (Górka et al. 2017). According to Gambuś et al. (2005), the phytoavailability of cadmium depends the most on soil $\mathrm{pH}$. It is most mobile at pH 4.5-5.5 (Jaworska 2009).

In our research, the content of other elements $(\mathrm{Pb}, \mathrm{Cu}, \mathrm{Ni}, \mathrm{Cr})$ was also determined in the solutions obtained after extraction with calcium chloride - it was a residual content regardless of incubation duration and experimental treatment.

\section{CONCLUSIONS}

1. Application of sulfur pulp significantly changed soil $\mathrm{pH}$, and the soil fertilized with the highest dose of pulp and with ammonium sulfate had the highest acidification.

2. Liming increased the rate of sulfur oxidation application of sulfur pulp at doses 10, 20, 30 and $60 \mathrm{mg} \mathrm{S} \cdot \mathrm{kg}^{-1}$ of soil led to a statistically significant (and proportional to the dose) increase in sulfate sulfur content in the soil. In the unlimed soil, the statistically significant increase in sulfate sulfur content was obtained only after the introduction of the two highest pulp doses. Intensity of transformations of sulfur pulp (at doses 10, 20, 30 and $60 \mathrm{mg} \mathrm{S} \cdot \mathrm{kg}^{-1} \mathrm{~d} . \mathrm{m}$. of soil) into sulfate form amounted to $100 \%$, $73.9 \%, 90.6 \%$ and $98.0 \%$, respectively, in the limed soil, whereas in the unlimed soil - to $14.3 \%, 31.8 \%, 38.4 \%$ and $61.3 \%$.

3. Application of sulfur in the form of ammonium sulfate at a dose of $20 \mathrm{mg} \mathrm{S} \cdot \mathrm{kg}^{-1} \mathrm{~d}$.m. of soil increased sulfate sulfur content in the unlimed soil comparably to application of elemental sulfur at a dose of $30 \mathrm{mg} \mathrm{S} \cdot \mathrm{kg}^{-1}$. Application of ammonium sulfate also significantly increased sulfate sulfur content in the limed soil; the content was significantly higher than after application of sulfur pulp at doses of 10,20 and $30 \mathrm{mg} \mathrm{S} \cdot \mathrm{kg}^{-1}$.

4. Application of sulfur pulp (at a dose of 20, 30 and $60 \mathrm{mg} \mathrm{S} \cdot \mathrm{kg}^{-1} \mathrm{~d} . \mathrm{m}$. of soil) changed the content of soluble forms (extracted with $0.1 \mathrm{~mol} \cdot \mathrm{dm}^{-3} \mathrm{CaCl}_{2}$ solution) of selected trace elements in the soil. A significant increase in the content of zinc, manganese and cadmium was observed.

5. Based on the obtained conclusions, it was established that waste sulfur pulp obtained in the process of biogas desulfurization may be used to increase sulfate sulfur content in soils (particularly in soils with regulated reaction), but its application may lead to a decrease in soil $\mathrm{pH}$ and an increase in the mobility of trace elements in soil (Zn, Mn, Cd). 
This Research was financed by the Ministry of Science and Higher Education of the Republic of Poland.

\section{REFERENCES}

Baran S. \& Turski R., 1999. Ćwiczenia specjalistyczne z utylizacji odpadów i ścieków. Wyd. AR w Lublinie, Lublin.

Barbusiński K., 2016. Innowacyjne technologie oczyszczania ścieków komunalnych - kierunki rozwoju. Napędy i Sterowanie, 1, 40-45.

Barczak B., Klikocka H., Kozera W. \& Gęsiński K., 2016. Wskaźniki stanu odżywienia łubinu wąskolistnego ( $\mathrm{Lu}$ pinus Angustifolius L.) siarką w zależności od formy i dawki tego pierwiastka. Zeszyty Problemowe Postępów Nauk Rolniczych, 584, 3-11.

Bolan N.S., Adriano D.C., Mani P.A. \& Duraisamy A., 2003. Immobilization and phytoavailability of cadmium in variable charge soils. II. Effect of lime addition. Plant and Soil, 251, 187-198.

Brzeziński M. \& Sosulski T., 2009. Wpływ wieloletniego nawożenia na zawartość ruchomych form manganu i żelaza w glebie lekkiej. Zeszyty Problemowe Postępów Nauk Rolniczych, 541, 73-79.

Burzyńska I., 2009. Wpływ odczynu gleby na współzależność między zawartością rozpuszczalnych form cynku w układzie: gleba - roślinność łąkowa. Ochrona Środowiska i Zasobów Naturalnych, 40, 246-253.

Curyło T., Gambuś F., Grzywnowicz I., Jasiewicz Cz., Kopeć M., Filipek-Mazur B., Stępień-Okluśnik S., Rogóż A. \& Wiśniowska-Kielian B., 2007. Przewodnik do ćwiczeń z chemii rolnej. Red. E. Gorlach. Wydawnictwo AR, Kraków.

Kuziemska B., Kalembasa D. \& Kalembasa S., 2014. Wpływ wapnowania i dodatku materiałów organicznych na zawartość wybranych metali w kupkówce pospolitej uprawianej na glebie zanieczyszczonej niklem. Acta Agrophysica, 21, 3, 293-304.

Filipek T. \& Skowrońska M., 2013. Aktualnie dominujące przyczyny oraz skutki zakwaszenia gleb użytkowanych rolniczo w Polsce. Acta Agrophysica, 20, 2, 283-294.

Gambuś F., Rak M. \& Wieczorek J., 2005. Rozpuszczalność kadmu w różnych glebach i jego pobieranie przez owies i rzepak. Roczniki Gleboznawcze, 56, 1/2, 49-57.

Goulding K.W.T., 2016. Soil acidification and the importance of liming agricultural soils with particular reference to the United Kingdom. Soil, Use and Management, 32, 3, 390-399.

Górka A., Kogut A. \& Krzystyniak A., 2017. Zawartość wybranych metali ciężkich - ołowiu i kadmu w glebach, i ich toksyczny wpływ na rozwój roślin. Analit, 3, 32-39.

Haling R.E., Simpson R.J., Culvenor R.A., Lambers H. \& Richardson A.E., 2011. Effect of soil acidity, soil strength and macropores on root growth and morphology of perennial grass species differing in acid-soil resistance. Plant, Cell and Environment, 34, 444-456.

Hoffmann J., Skut J. \& Zmuda J., 2014. Badanie zawartości wybranych form fosforu w częściowo rozłożonych fosforytach wzbogaconych w siarkę. Proceedings of ECOpole, $8(2), 513-518$
Hřivna L., Richter R., Lošák T. \& Hlušek J., 2002. Effect of increasing doses of nitrogen and sulphur on chemical composition of plants, yields and seed quality in winter rape. Rostlinná Výroba, 48(1), 1-6.

Jackowska I. \& Bojanowska M., 2000. Badania nad formami i rozpuszczalnością metali ciężkich w glebie lessowej. Roczniki Gleboznawcze, 50, 51-63.

Jaworska H., 2009. Profilowa dystrybucja oraz mobilność ołowiu i kadmu w glebie uprawnej o zróżnicowanym uziarnieniu. Ochrona Środowiska i Zasobów Naturalnych, 40, 65-69.

Jaworska H., 2012. Mangan całkowity oraz jego formy mobilne w wybranych glebach płowych z okolic Huty Miedzi Głogów. Proceedings of ECOpole, 6(2), 731-736.

Kabata-Pendias A., Piotrowska M., Motowicka-Terelak T., Maliszewska-Kordybach B., Filipiak K., Krakowiak A. \& Pietruch Cz., 1995. Podstawy oceny chemicznego zanieczyszczenia gleb. Metale ciężkie, siarka $i$ WWA. Biblioteka Monitoringu Środowiska. Państwowa Inspekcja Ochrony Środowiska, Instytut Uprawy Nawożenia i Gleboznawstwa, Warszawa.

Kaczor A. \& Zuzańska J., 2009. Znaczenie siarki w rolnictwie. Chemistry-Didactics-Ecology-Meteorology, 14, 1-2, 69-78.

Klikocka H. \& Sachajko J., 2011. Kompleksowa ocena agrotechnologii ziemniaka i pszenżyta jarego. Acta Agrophysica - Instytut Agrofizyki im. Bohdana Dobrzańskiego PAN w Lublinie. Rozprawy i Monografie, 4(195), Instytut Agrofizyki im. Bohdana Dobrzańskiego PAN, Lublin.

Klikocka H., Szostak B., Gaj R., Głowacka A. \& Narolski B., 2015. Pobranie fosforu z ziarnem pszenżyta jarego na tle uprawy roli i nawożenia mineralnego oraz właściwości chemicznych gleby. Polish Journal of Agronomy, 21, 3-10.

Kociołek-Balawejder E. \& Wilk Ł., 2011. Przegląd metod usuwania siarkowodoru z biogazu. Przemyst Chemiczny, 90, 3, 389-397.

Kowalczyk-Juśko A., 2013. Biogazownie szansą dla rolnictwa iśrodowiska. Red. A. Grzybek. Fundacja na Rzecz Rozwoju Polskiego Rolnictwa, Warszawa.

Krzemień J., 2012. Produkcja i wykorzystanie biogazu w oczyszczalniach ścieków w województwie śląskim. Ochrona Środowiska i Zasobów Naturalnych, 4, 54, 210-220.

Kulczycki G., 2004. Wpływ nawożenia siarką elementarną na zawartość mikroelementów w roślinach i glebach. Zeszyty Problemowe Postępów Nauk Rolniczych, 502, 207-213.

Kulczycki G., Pląskowska E., Matkowski K. \& Moszczyńska E., 2007. Wpływ nawożenia siarką elementarną na liczebność i skład gatunkowy zbiorowisk grzybów w glebie. Zeszyty Problemowe Postępów Nauk Rolniczych, 520, 525-530.

Kuziemska B., Pieniak-Lendzion K., Trębicka J., Wieremiej W. \& Klej P., 2015. Alternatywne źródła energii. Zeszyty Naukowe Uniwersytetu Przyrodniczo-Humanistycznego w Siedlcach. Administracja i Zarzadzanie, 33, 89-107.

Kwaśny J., Balcerzak W. \& Rezka P., 2016. Biogaz i charakterystyka wybranych metod jego odsiarczania. Czasopismo Inżynierii Lądowej, Środowiska i Architektury, 63, 2/I, 129-141.

Lošák T., Čermák P. \& Hlušek J., 2012. Changes in fertilisation and liming of soils of the Czech Republic for the last 20 years. Archives of Agronomy and Soil Science, 58, $1,238-242$. 
Monitoring chemizmu gleb ornych Polski, [on-line:] http:// www.gios.gov.pl/chemizm_gleb/index.php?mod=wyniki\&cz=E [access: 17.01.2018].

Mudlaff K., Staniszewska K. \& Ordon L., 2016. Analiza zasolenia, odczynu oraz aktywności katalazy w glebie na terenie Ojcowskiego Parku Narodowego w warunkach zróżnicowanego ruchu turystycznego. Analit, 1, 32-41.

Nazarkiewicz M. \& Kaniuczak J., 2012. Wpływ wapnowania i nawożenia mineralnego na zawartość rozpuszczalnych form pierwiastków śladowych w glebie płowej. Roczniki Gleboznawcze, 63, 17-23.

Onwuka M.I., Ozurumba U.V. \& Nkwocha O.S., 2016. Changes in soil $\mathrm{pH}$ and exchangable acidity of selected parent materials as influenced by amendments in south east of Nigeria. Journal of Geoscience and Environmental Protection, 4, 80-88.

Operating instructions vario MAX cube analyzer, 2013. Elementar Analysensysteme GmbH. Version 12.11.2013.

Ostrowska A., Gawliński S. \& Szczubiałka Z., 1991. Metody analizy i oceny właściwości gleb i roślin. Katalog. IOŚ, Warszawa.

Pietrzak S., 2015. Zawartość siarki w glebach użytków zielonych w Polsce w latach 2009-2011. Woda-Środowisko-Obszary Wiejskie, 15, 2, 97-113.

Piskowska-Wasiak J., 2013. Uzdatnianie gazów pochodzenia biologicznego w celu wytwarzania biopaliw i biokomponentów. Nafta-Gaz, 69, 3, 241-255.

PN-EN 15925:2011. Nawozy - ekstrakcja siarki całkowitej obecnej w różnych postaciach.

Podleśna A., 2005. Nawożenie siarką jako czynnik kształtujący metabolizm roślin uprawnych i jakość płodów rolnych. Pamiętnik Puławski, 139, 161-172.

Rajmund A. \& Bożym M., 2017. Zmiany zawartości żelaza i manganu w glebie lekkiej nawożonej osadami ściekowymi i kompostami w czasie 6-letniego doświadczenia lizymetrycznego. Woda-Środowisko-Obszary Wiejskie, $17,1,101-113$.

Rengel Z., 2015. Availability of Mn, Zn and Fe in the rhizosphere. Journal of Soil Science and Plant Nutrition, 15(2), 397-409.

Rozporządzenie, 2008. Rozporzadzenie Ministra Rolnictwa i Rozwoju Wsi z dnia 18 czerwca 2008 r. w sprawie wykonania niektórych przepisów ustawy o nawozach i nawożeniu. Dz.U. 2008, nr 119 poz. 765.
Rozporządzenie, 2010. Rozporzadzenie Ministra Gospodarki $z$ dnia 8 września 2010 r. w sprawie sposobu pakowania nawozów mineralnych, umieszczania informacji o składnikach nawozowych na tych opakowaniach, sposobu badania nawozów mineralnych oraz typów wapna nawozowego. Dz.U. 2010, nr 183, poz. 1229.

Rozporządzenie, 2015a. Rozporządzenie Ministra Środowiska $z$ dnia 6 lutego 2015 r. w sprawie komunalnych osadów ściekowych. Dz. U. 2015, poz. 257.

Rozporządzenie, 2015b. Rozporządzenie Ministra Środowiska $z$ dnia 20 stycznia 2015 r. w sprawie procesu R10. Dz.U. 2015, poz. 132.

Sadecka Z., 2010. Podstawy biologicznego oczyszczania ścieków. Wyd. Seidel-Przywecki, Warszawa.

Šípalová M., Lošák T., Hlušek J., Vollmann J., Hudec J., Filipčík R., Macek M. \& Kráčmar S., 2011. Fatty acid composition of Camelina sativa as affected by combined nitrogen and sulphur fertilisation. African Journal of $A g$ ricultural Research, 6, 16, 3919-3923.

Tkaczyk P. \& Bednarek W., 2011. Ocena odczynu gleb Lubelszczyzny. Acta Agrophysica, 18, 1(92), 173-186.

Ustawa, 2017. Ustawa $z$ dnia 10 lipca 2007 r. o nawozach i nawożeniu. 2007. Consolidated text: Dz. U. 2017 poz. 668.

Vollmann J., Lošák T., Pachner M., Watanabe D., \& Hlušek J., 2015. Soybean cadmium concentration: validation of a QTL affecting seed cadmium accumulation for improved food safety. Euphytica, 203, 1, 177-184.

Wen G., Schoenau J.J., Yamamoto T. \& Inoue M., 2001. A model of oxidation of an elemental sulfur fertilizer in soil. Soil Science, 166, 607-613.

Wysokiński A., 2011. Zawartość żelaza i manganu w roślinach nawożonych osadami ściekowymi kompostowanymi z CaO i popiołem z węgla brunatnego. Ochrona Środowiska i Zasobów Naturalnych, 49, 108-116.

Yang Z.H.,Stoven K., Haneklaus S., Singh B.R., Schung E., 2010. Elemental sulfur oxidation by Thiobacillus spp. and aerobic heeterotrophic sulfur-oxidizing bacteria. Pesdosphere, 20, 1, 71-79.

Zaniewicz-Bajakowska A., Rosa R. Franczuk J. \& Kosterna E., 2009. Wapnowanie gleby a akumulacja kadmu w buraku ćwikłowym. Ochrona Środowiska i Zasobów Naturalnych, 41, 377-384.

Żarczyński A., Rosiak K., Anielak P. \& Wolf W., 2014. Praktyczne metody oczyszczania biogazu $\mathrm{z}$ siarkowodoru. Cz. 1. Zastosowanie sorbentów stałych. Acta Innovations, $12,24-34$. 